\title{
Effects of replacing groundnut cake with
rumen content supplemented with or without enzyme in the diet of weaner rabbits
}

\author{
A. A. Adeniji, S. Rumak and R. A. Oluwafemi
}

\section{Abstract}

Background: Rabbits are also herbivores which efficiently convert fodder to They a prolific and converter of plant proteins of little or no use to people as food into high-value animah te Dabbit meat is high in protein, low in calories and low in fat and cholesterol contents, being considered as a vlicacy and a healthy food product. Feeding rabbits with concentrates is expensive and therefore in orde reduce, lost of production, hence the use of rumen content in this study as alternative feedstuff without compelitio

Methods: A total of thirty six (36) weaner rabbits (oryctalagus cuniculus) of different body weight and age where use in this experiment to determine the effects of replacing ra. n content with or without enzyme supplementation for groundnut cake. This feeding trial $w$, las $d$ for 8 weeks was carried out in order to determine the replacement value of groundnut cake with ru. so content with or without enzyme in the diet of weaner rabbit. A 3×2 factorial experiment was ad ed such that there where three (3) replacement level of rumen content $(0,25$ and $50 \%)$ for groundnut cake py two pplemental level (no enzyme and enzyme supplement).

Results: The results showed that increased 1s. sion leyel of rumen content has significant effects $(p<0.05)$ on daily feed intake, rate of weight gain, fe do ga ratio, nitrogen retention, faecal nitrogen, total nitrogen output and nitrogen digestibility. The weigh gained by babbits fed on 0,25 and $50 \%$ were all comparable $(p>0.05)$ with weight gained value of $7.62,7.44$ an $7.36 \mathrm{~g}$ r spectively. Similarly there was a significant $(p<0.05)$ effect of supplement added on the body weig, of the experimental animals. There was significant effect $(p<0.05)$ of the diet on the obtained feed ain ratio. However, there was no significant effect $(p>0.05)$ of the treatment on urinary nitrogen. Significant ( $p-0.0$ s effects of supplementation was observed on the feed intake, weight gain, feed to gain ratio, faecar rogeh nitrogen retention and nitrogen digestibility but there was no significant effects $(p>0.05)$ of the sur $m$, $m$ on the nitrogen intake. The interaction between the varying levels of rumen content supplennentatic had significant effects $(p<0.05)$ on the feacal nitrogen, feed intake and feed to gain ratio but no significa $(p<0.0,0)$ effects on interaction of nitrogen intake.

Conclusich: In col sion, since the results from this study showed no negative effects on the performance of the experi ental animals, the test ingredient can be used as alternative feedstuff at a lower inclusion level so as to reduce duct on cost and expand rabbit production.

Key lords:, rabbits, Groundnuts cake, Rumen contents and enzyme

* Correspondence: oluwafemi.adebisi@uniabuja.edu.ng

Department of Animal Science, Faculty of Agriculture, University of Abuja,

P.M.B 117, FCT-Abuja, Nigeria

\section{Biomed Central}

(c) 2015 Adeniji et al. Open Access This article is distributed under the terms of the Creative Commons Attribution 4.0 International License (http://creativecommons.org/licenses/by/4.0/), which permits unrestricted use, distribution, and reproduction in any medium, provided you give appropriate credit to the original author(s) and the source, provide a link to the Creative Commons license, and indicate if changes were made. The Creative Commons Public Domain Dedication waiver (http://creativecommons.org/publicdomain/zero/1.0/) applies to the data made available in this article, unless otherwise stated. 


\section{Background}

Rabbits are also herbivores which efficiently convert fodder to food. They are prolific and converter of plant proteins of little or no use to people as food into highvalue animal protein. In an efficient breeding, rabbits convert up to $20 \%$ of the protein consumed in meat, more than for pigs (15-18 \%) and cattle (9-12 \%) [1]. Rabbit meat is high in protein, low in calories and low in fat and cholesterol contents, being considered as a delicacy and a healthy food product, easy to digest, indicated in feeding children and old people [2]. Rabbit meat is one of the best white lean meats available on the market, very tender and juicy. There is no religious taboo or social stigma regarding the consumption of this meat.

In Nigeria, rabbit production is considered a part time venture hence majority of rabbit production are mainly family own with small number of stock. Commercial productions are very rare and so the full potentials of rabbit are yet to be harnessed. Considering the economic and nutritional benefits of rabbit production which has been severally studied and confirmed, rabbit production need to be encouraged even now that Nigeria is in search of economic recovery strategies.

The major cost in any livestock production is feed thus feeding cost is a major problem facing rabbit production. Conventional protein feedstuffs such as soya bean $\mathrm{m} / \mathrm{dd}$, groundnut cake, and fish meal are quite expensiv Tie high cost of these ingredients has resulted in he feeding of rabbit. The need to source fo lternativ feedstuff (unconventional) so as to reduca hig ost of livestock production cannot be overe nphasized. amen content (RC) is obtained from the a attoir after slaughtering of animal. They are discarded a vaste and cannot be consumed by human.

There has been a tremendous ease in interest and use of various typ dietary enzymes in swine diets to improve nu ient digest bility in recent years. Enzymes are bichaic active proteins that break specific chemi bonds telease nutrients for further digestion and at rption. Enzymes that breakdown proteins are called, oteases, lipases breakdown fats, and the steveral carbohydrases that breakdown carbohydı $\mathrm{s} t \mathrm{~s}$ allow them to be better digested and osol ed as energy sources [3]. Feed stuffs including u. annal ones used in animal feeding is composi of plant material, cereal and vegetable proteins which cannot be fully digested and utilized by animals, hence the need for enzyme supplementation which is known to assist in feed utilization and digestion.

\section{Method}

\section{Experimental site}

The experiment was carried out at the rabbitary unit of the department of Animal Science, Faculty of
Agriculture, University of Abuja farm, Federal Capital Territory (FCT) (Table 1).

\section{Experimental animals and their management}

Thirty six weaner rabbits of mixed breeds averaging $0.2 \mathrm{~kg}$ - $0.3 \mathrm{~kg}$ body weight and aged 5 week were purchased from NAPRI (National Animal P duction Research Institute Zaria). The rabbits on arriva the experimental site were housed in a metal hutch th wire mesh at the base for easy collectro of feaces and urine. The hutches were disinfected Defo the rabbits were introduced and they were gi en anti-stresos with antibiotics for seven days and all ed to adapt to the environment.

The rabbits were ran fomly a cated to six (6) dietary treatments with $\mathrm{ct} / 2$ rabsits per replicate and each treatment had thre 3) replicates. During the experiment, fea a water were supplied ad-libitum throughout an of the animals were monitored. Quan of feed consumed was monitored daily for weeks trial period by taking note of the difference brtwy en feed served and feed left after $24 \mathrm{~h}$. The rabbits were also weighed on weekly basis during th eriod to determine weight gain. The hutches vere cleaned on daily basis throughout the experintal period. Feeders and drinkers were made available in each hutch since experimental animals were housed and fed differently.

\section{Experimental design}

The rabbits were allocated to six (6) dietary treatments in a Completely Randomized Design (CRD) each treatment had three (3) replicates with two rabbits per replicate. Each rabbit was fed adlibitum diet and water for the eight (8) weeks study period. The six experiment diets had rumen content replacing GNC at 0, 25, $50 \%$ dietary levels.

\section{Parameter / data collected}

The performance of the rabbits was monitored, the initial live weight of the rabbits were recorded at commencement of the experiment, weekly weight and daily feed intake were recorded, while feed to gain ratio were also recorded and cost implication were calculated. During the last week of the study (the $8^{\text {th }}$ week), the faeces and the urine of the rabbits were collected by the total faeces collection and the urine method and the nitrogen in it was analyzed. The nitrogen digestibility was also calculated.

\section{Chemical analysis}

Proximate analysis was conducted using the method of Association of Official Analytical Chemist (AOAC) [4]. 
Table 1 Composition of experimental diet ( $\mathrm{Kg} / 100 \mathrm{~kg})$

\begin{tabular}{|c|c|c|c|c|c|c|}
\hline \multirow{3}{*}{ Ingredients } & \multicolumn{6}{|c|}{ Levels of rumen content replacement for groundnut cake (\%) } \\
\hline & \multicolumn{2}{|l|}{$0 \%$} & \multicolumn{2}{|l|}{$25 \%$} & \multicolumn{2}{|l|}{$50 \%$} \\
\hline & $\mathrm{T} 1$ & $\mathrm{~T} 2$ & T3 & T4 & T5 & T6 \\
\hline Rumen content & 0 & 0 & 4.5 & 4.5 & 9 & 9 \\
\hline GNC & 18 & 18 & 13.5 & 13.5 & 9 & \\
\hline Enzyme & 0 & + & 0 & + & 0 & \\
\hline Maize & 40 & 40 & 40 & 40 & 40 & \\
\hline Fishmeal & 1 & 1 & 1 & 1 & 1 & \\
\hline Maize offal & 14 & 14 & 14 & 14 & 14 & . \\
\hline Rice bran & 7.3 & 7.3 & 7.3 & 7.3 & & 7.3 \\
\hline Wheat offal & 14.2 & 14.2 & 14.2 & 14.2 & & 14.2 \\
\hline Bone meal & 3 & 3 & 3 & 3 & & 3 \\
\hline Limestone & 1.7 & 1.7 & 1.7 & 1.7 & & 1.7 \\
\hline Salt & 0.35 & 0.35 & 0.35 & 0 & 0.35 & 0.35 \\
\hline Premix & 0.25 & 0.25 & 0.25 & & 0.25 & 0.25 \\
\hline Lysine & 0.10 & 0.10 & 0.10 & & 0.10 & 0.10 \\
\hline Methionine & 0.10 & 0.10 & 0.10 & & 0.10 & 0.10 \\
\hline Total & 100 & 100 & 100 & & 100 & 100 \\
\hline \multicolumn{7}{|c|}{ Analyzed proximate values } \\
\hline Crude protein (\%) & 17.57 & 17.57 & & 16.31 & 15.08 & 15.08 \\
\hline Crude fiber (\%) & 5.51 & 5.51 & & 7.13 & 8.73 & 8.73 \\
\hline Ether extract (\%) & 4.52 & 4.52 & & 4.37 & 4.23 & 4.23 \\
\hline M.E cal/kg & 2701.40 & 2701 & 26 & 2685.35 & 2669.09 & 2669.09 \\
\hline Moisture (\%) & 8.61 & & .57 & 8.57 & 8.54 & 8.54 \\
\hline Total Ash & 12.28 & $12 \%$ & 12.77 & 12.77 & 11.95 & 11.95 \\
\hline $\begin{array}{l}\text { BioMix Grower (BIOO } \\
\text { VitD3 }=1,500,000, \text { vit } \\
\text { pentatonicacid }=550 \\
\text { cholinechloride }=175 \\
\text { manganese }=40,000 \\
{ }^{*} \text { Recommended incl } \\
\text { Source: Field researcl }\end{array}$ & $\begin{array}{l}\text { rimix used } \\
\text {, vitk }=150 \\
=2000 \mathrm{mg}, \\
\text { balt }=200 \mathrm{n} \\
\mathrm{m}=200 \mathrm{~m} \\
\text { f enzyme: } \\
\text { ching and }\end{array}$ & grain: & $8,000,0$ & & & \\
\hline
\end{tabular}

Sample of the test di an faeces were analyzed for the proximate constit...nts ing tne method.

\section{Data analysis}

All data stained we subjected to analysis of variance (ANOr u ing factorial design of Completely Randomized Desig CRD) Model and significant differences be+ veer mean were separated using Duncan Multiple h $<$ [5].

\section{Resuits}

The results of the growth performance characteristics measured are presented in Table 2. The result showed that the feed intake of $50.85 \mathrm{~g} / \mathrm{rabbit} /$ day in rabbit fed $0 \%$ rumen content level was significantly higher $(p<$ $0,05)$ while rabbit fed on $25 \%$ rumen content had an intake of $50.04 \%$ which is significantly $(p<0.05)$ higher than $49.79 \mathrm{~g}$ consumed by rabbit fed $50 \%$ rumen content. Rabbits fed on enzyme supplemented diet had a higher feed intake value (50.26 g) when compared with rabbits fed on experimental diets without enzyme which had $50.19 \mathrm{~g}$.

The weight gained by rabbits fed on 0,25 and $50 \%$ were significantly dofferent $(p<0.05)$ with weight gained value of 7.62,7.44 and 7.36 g respectively. Similarly there was a significant $(p<0.05)$ effect of supplementation on the observed body weight gain value obtained by the experimental animals. There was also significant effects $(p<0.05)$ of the diet on the obtained feed to gain ratio. The rabbits fed $0 \%$ rumen content diets had the best feed to gain ratio of $6.72 \mathrm{~g}$ when compared with rabbits on other experimental diets. Rabbits fed experimental diet containing 50 \% rumen content had the poorest feed to gain ratio of $6.90 \mathrm{~g}$ when compared with rabbits on other experimental diets. 
Table 2 Growth performance characteristics of weaner rabbits fed rumen content with or without enzyme supplementation in replacing groundnut cake

\begin{tabular}{|c|c|c|c|c|c|}
\hline & \multicolumn{5}{|c|}{ ratio } \\
\hline \multicolumn{6}{|l|}{ Levels of Rumen content (\%) } \\
\hline 0 & $725.00^{\mathrm{a}}$ & $1152.00^{\mathrm{a}}$ & $49.79^{c}$ & $7.52^{\mathrm{a}}$ & \\
\hline 25 & $675.00^{b}$ & $1091.00^{\mathrm{b}}$ & $50.10^{\mathrm{b}}$ & $7.44^{\mathrm{b}}$ & \\
\hline 50 & $650.00^{c}$ & $1062.00^{c}$ & $50.45^{\mathrm{a}}$ & $7.36^{c}$ & \\
\hline SEM & 33.0945 & 39.5609 & 0.4801 & 0.1163 & \\
\hline Significance & * & * & * & * & \\
\hline \multicolumn{6}{|l|}{ Supplements } \\
\hline No Supplement & $675.00^{b}$ & $1108.33^{\mathrm{a}}$ & $50.19^{b}$ & & $6.80^{\mathrm{a}}$ \\
\hline \multicolumn{6}{|l|}{ Added (NSA) } \\
\hline Enzyme & $691.00^{\mathrm{a}}$ & $1096.67^{b}$ & $50.26^{\mathrm{a}}$ & & $6.72^{\mathrm{b}}$ \\
\hline \multicolumn{6}{|l|}{ (Maxigrain) } \\
\hline SEM & 9.1524 & 6.9342 & 0.0394 & $0.03,4$ & 0.0394 \\
\hline Significance & * & * & * & & * \\
\hline $\begin{array}{l}\text { Rumen content Supplement } \\
\text { (interaction) }\end{array}$ & * & NS & * & * & * \\
\hline
\end{tabular}

The nitrogen intake of $3.58 \mathrm{~g} / \mathrm{rabbit} /$ day $(\mathrm{T} / \mathrm{g})$ from the experimental animals fed on the cortrol t was significantly higher $(p<0.05)$ than $t / 2$ fed 0 other rumen content levels. The experimental ts had no significant effect $(p>0.05)$ on nirogen inta, between the experimental animals fed tzyme and non enzyme supplemnted diets. The feacal troger of rabbits

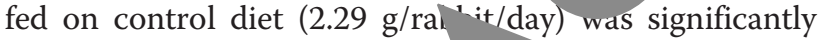
higher $(p<0.05)$ than those fed $\mathrm{O}_{1}$ and $50 \%$ rumen content level that had $6 \mathrm{~g} /$ abbit/day and $2.23 \mathrm{~g} /$ rabbit/day respective Sin larly t/nere was no significant $(p>0.05)$ effect $\mathrm{su}_{1}$ ementation no the observed feacal values of ned on $c$ experimental rabbits.

The nitroge $1 \mathrm{dic}_{\mathrm{c}}$ tibility of $64.96 \%$ in weaner rabbits fed on $50 \%$ rumen $y$ tent diet was significantly higher $(p<0 \%$ th $n$ those fed on 0 and $25 \%$ rumen content level that 63.97 and $64.21 \%$ respectively. Similarly there vas sig ifficant $(p<0.05)$ effect of supplementation a. ac erved nitrogen digestibility of the experimental à mals.

\section{Discussion}

The variation in weight gain per day at different level of rumen content inclusion in the study is in conformity with several reports which indicated that rate of gain reduces with increased amount of crude fibre in the diets of monogastric animals [6]. This result contradicts the results of [7] who reported no significance difference
$(P)>0.05)$ when rumen content was replaced with soya Deans in the diet of broiler finisher.

The significant increase $(P<0.05)$ in feed intake as the level of rumen content increased from 0 to $50 \%$ could be because animal consumes more feed to meet its energy requirement. Also, it may be because rabbit being a pseudo-ruminant tolerates considerable level of fiber in their diet [8]. The significant increases in daily feed intake and non-significant difference in daily weight gain observed in this work agree with the results of [9] who fed bovine rumen content and reported that increasing the RC level in the diets significantly increased feed consumption but with non-significant difference in growth rate. Alawa and Umunna [10] stated that the inclusion of agro-industrial by products in livestock rations has often resulted in increased feed intake as a compensation for the reduced energy concentration of such diets. In terms of supplement, rabbits fed enzyme supplemented diets are significantly $(p<0.05)$ better than rabbits fed no supplement. This may be because enzyme increases the intake of feed.

The utilization of feed decreased from 0 to $50 \%$ inclusion level of rumen content. This result is in agreement with the reports of [11] who reported significant effects of blood rumen content on poultry but did conform with the reports of [9] who fed rabbit with rumen content. In term of supplement, rabbit fed enzyme supplemented rumen content had better feed utilization 
Table 3 Nitrogen digestibility of weaner rabbits fed rumen content with or without enzyme supplementation in replacing groundnut cake

\begin{tabular}{|c|c|c|c|c|c|c|}
\hline & $\begin{array}{l}\text { Nitrogen } \\
\text { intake (g/day) }\end{array}$ & $\begin{array}{l}\text { Feacal } \\
\text { Nitrogen (g/day) }\end{array}$ & $\begin{array}{l}\text { Urinary } \\
\text { Nitrogen }\end{array}$ & $\begin{array}{l}\text { Total nitrogen } \\
\text { Output }\end{array}$ & $\begin{array}{l}\text { Nitrogen } \\
\text { retained (g) }\end{array}$ & $\begin{array}{l}\text { Nitrogen } \\
\text { digestibility (\%) }\end{array}$ \\
\hline \multicolumn{7}{|l|}{ Levels of Rumen content (\%) } \\
\hline 0 & $3.58^{a}$ & $2.29^{a}$ & $0.47^{\mathrm{a}}$ & $0.49^{a}$ & $1.24^{c}$ & \\
\hline 25 & $3.53^{b}$ & $2.26^{b}$ & $0.45^{\mathrm{a}}$ & $0.45^{b}$ & $1.26^{b}$ & \\
\hline 50 & $3.51^{c}$ & $2.23^{c}$ & $0.46^{\mathrm{a}}$ & $0.41^{c}$ & $1.29^{\mathrm{a}}$ & \\
\hline SEM & 0.0113 & 0.0065 & 0.0033 & 0.0052 & 0.0053 & \\
\hline Significance & * & $*$ & NS & * & 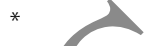 & \\
\hline \multicolumn{7}{|l|}{ Supplements } \\
\hline NSA & $3.54^{a}$ & $2.29^{a}$ & $0.46^{\mathrm{a}}$ & $0.43^{b}$ & & $64.37^{\mathrm{a}}$ \\
\hline Enzyme & $3.53^{a}$ & $2.26^{\mathrm{b}}$ & $0.47^{\mathrm{a}}$ & $0.48^{a}$ & & $64.33^{b}$ \\
\hline \multicolumn{7}{|l|}{ (Maxigrain) } \\
\hline SEM & 0.0043 & 0.0097 & 0.0037 & 0.0058 & & 0.0873 \\
\hline Significance & NS & $*$ & NS & & * & * \\
\hline Rumen content*Supplement & NS & $*$ & NS & & * & * \\
\hline \multicolumn{7}{|c|}{$\begin{array}{l}\text { SEM- Standard Error of mean } \\
\text { Means with different superscripts along the same column are significantly different }(P<0.05) \\
\text { NS- Not significantly different }(P>0.05) \\
\text { SEM- Standard Error of mean } \\
\text { Means with different superscripts }(a, b, c) \text { along the same column are significantly different }(P<0.05)\end{array}$} \\
\hline
\end{tabular}

compared with rabbit fed no supplement. The significan increase in feed to gain ratio in this study is in contrast with the work of [12] who replaced maize with me n content in the diet of a weaner rabbit.

The result showed that the nitrogen intar increase as the level of rumen content increased the "erence in the nitrogen intake could be attrib ated to the afference in the crude protein content of the diets. This result contradicts the work reporte ov [12] who observed insignificance differen when rumen content maggot meal mixture was fed in thy $r$ of early weaned piglet. In terms of sup nent, the result showed that there were higher va ss o nitrogen intake in rabbit fed with enzyme supp" me tion when compared to rabbits fed no supplen t. This ay be because of the activity of enzyme in the

There as significa $c$ increase in the nitrogen digested with in in the level of rumen content. This may be as a mesuli cry de protein content of the diet. This is in ontr st wit the findings of [12] who reported no $\mathrm{S}_{2}$.1cum difference in the nitrogen digested with the inch $g$ in the inclusion level of rumen content maggot meal in the diets of early weaned pig. The result showed that there were higher values of nitrogen digested in rabbit fed with no supplementation as compared to those fed enzyme supplementation. This may be as a result protein content of the diet.

There was significant difference in the nitrogen digestibility as observed with varying levels of rumen content. This may suggest that the crude fibre contents in all the dieta treatment were different and therefore, did affect d gestibility of the rabbits. However, other reports which contradict this result indicated that nitrogen digestibility was lowered with increase in the level of rumen content [12].

\section{Conclusion}

In conclusion, since the results from this study showed no negative effects on the performance of the experimental animals, the test ingredient can be used as alternative feedstuff at a lower inclusion level so as to reduce production cost and expand rabbit production.

\section{Competing interests}

The authors declare that they have no competing interests.

\section{Authors' contributions}

$\mathrm{AA}^{\prime}$ is the first author and he was involved in planning, experimental design, feed formulation and coordination of the research. $S^{\prime}$ is the research assistant and he was involved in day to day running of the experiment under the supervision of AA an RA. He was also involved in data collection. RA' is the second supervisor. He was involved in supervision, data arrangement, analysis, compilation of result and report writing. He is the corresponding author. All authors read and approved the final manuscript.

Received: 13 September 2015 Accepted: 24 November 2015

Published online: 18 December 2015

\section{References}

1. Suttle NF. Mineral nutrition of livestock. 4th ed. Oxfordshire, UK: CAB International; 2010.

2. Dalle Zotte A. Main factors influencing the rabbit carcass and meat quality. Valencia, Spain: Proceedings of the 7th World Rabbit Congress; 2000. p. 1-32.

3. $\mathrm{Xu}$ G. The role of feed enzymes in swine feeding programs. Marshall, MN: Midwest Ag Enterprises; 2008. 
4. A.O.A.C. Association of official analytical chemists. Washington D.C: Official methods of analysts15th ed; 1990.

5. Steel RG, Torrie JH. Principles and procedure of statistics. New York: Mcgraw hill. Book company; 1980.

6. Numbela ER. Effect of replacing palm kernel cake with rice husk in the diets of growing pigs. Animal Prod J Vol. 2001;2(4):33-41.

7. Onu PN, Otuma MO, Odukwe CA, Aniebo AO. Effects of different levels of bovine rumen content on productive performance, carcass characteristics and economics of production of finisher broilers. Int J Food Agric Vet Sci. 2011:1(1):10-6.

8. Aduku OA, Dim NI, Aganga AA. Note on a comparative evaluation of palm kernel cake, peanut and sun flower meal in the diets of weaning rabbits. J Applied Rabbit Res. 1988;11:264-5.

9. Dairo FAS, Aina OO, Asafa AR. Performance evaluation of growing rabbits fed varying levels of rumen content mixture. Nig J Anim Prod. 2005;32(1):67-72.

10. Alawa JP, Umunna NN. Alternative feed formulation in developing countries: Prospects for utilization of Agro-Industrial by-products. J Anim Prod Res. 1993;13(2):63-98,

11. Adeniji AA, Balogun OO. Evaluation of rumen content mixture in the diets of starter chicks. Niger J Animal Prod. 2001;29(1):34-9.

12. Adeniji AA. Replacement value of maize with enzyme supplemented decomposed bovine rumen content in the diet of weaner rabbits. J Anim Vet Adv. 2008;3(2):104-8.
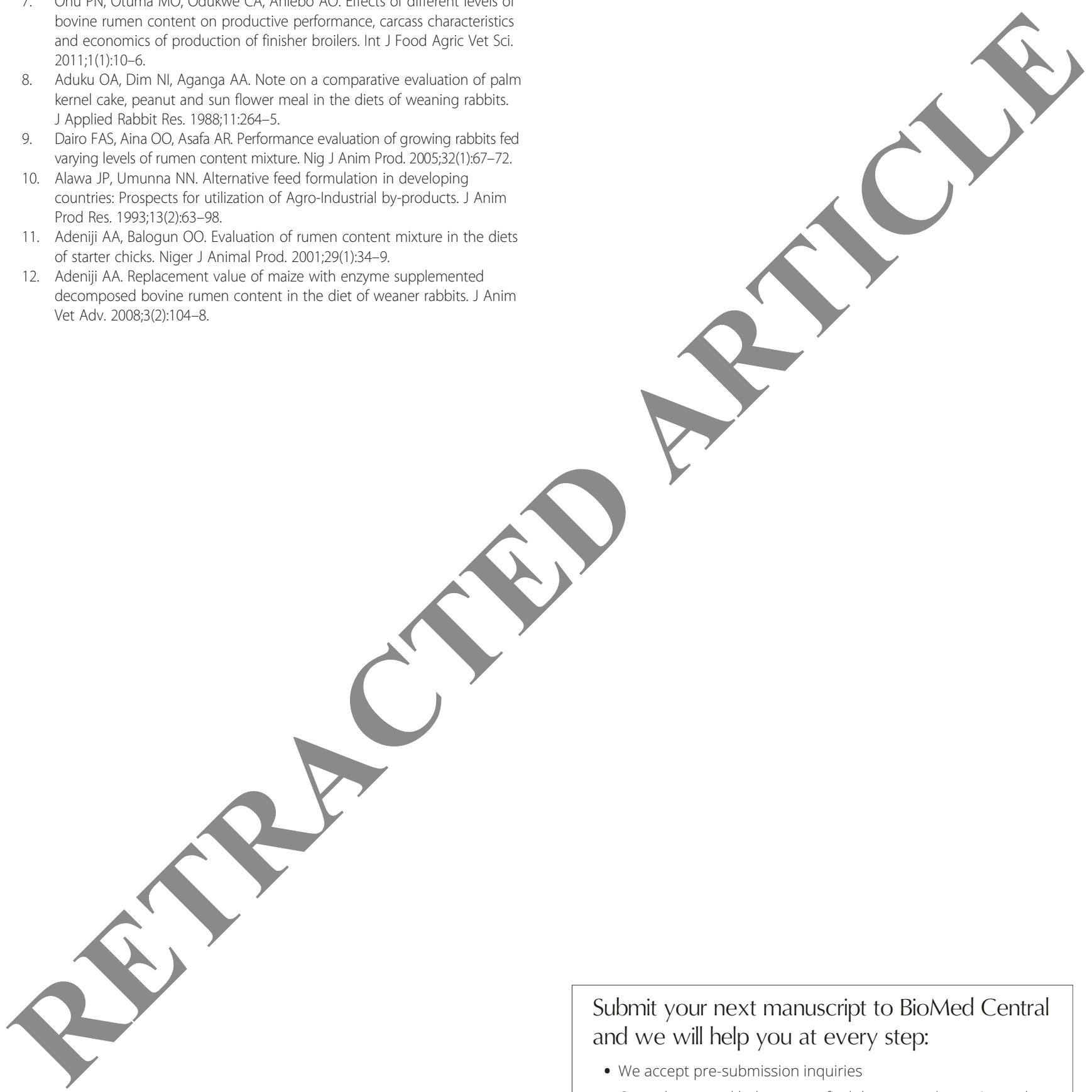

Submit your next manuscript to BioMed Central and we will help you at every step:

- We accept pre-submission inquiries

- Our selector tool helps you to find the most relevant journal

- We provide round the clock customer support

- Convenient online submission

- Thorough peer review

- Inclusion in PubMed and all major indexing services

- Maximum visibility for your research 